\title{
Performance of 'Chambourcin' Winegrape on Nematode-resistant Rootstocks in Missouri
}

\author{
Andrew L. Thomas ${ }^{1}$, Jackie L. Harris ${ }^{2}$, Elijah A. Bergmeier ${ }^{3}$, \\ and R. Keith Striegler ${ }^{2}$
}

AdDITIONAL INDEX WORDs. graft, grape, viticulture, Vitis

Summary. One of the most popular winegrapes (Vitis sp.) for red wine production in the midwestern United States is 'Chambourcin', a French-American hybrid. It is typically produced on own-rooted vines in the region, but the potential benefits of grafting it to improved rootstocks are becoming better-known. Nematodes present occasional serious winegrape production challenges in the midwestern United States, and are capable of transmitting pathogenic viruses. New rootstocks developed by University of California, Davis (UCD GRN series) are resistant to several species and races of nematodes, but have not been evaluated under midwestern U.S. production conditions. A study with 'Chambourcin' grafted to four of these new nematode-resistant rootstocks ('UCD GRN-2', 'UCD GRN-3', 'UCD GRN-4', and 'UCD GRN-5') and 'Couderc 3309', along with own-rooted vines was established in 2010 in southwest Missouri, and fruited in 2013-15. Three of the nematode-resistant rootstocks (GRN-2, 3, 4) performed as well as the standard 'Couderc 3309' and own-rooted vines, with yields among all rootstocks ranging from 10 to $13 \mathrm{~kg} /$ vine. The rootstock 'UCD GRN-5' generally performed poorly, however, manifested by low pruning weights and a high Ravaz index value (25) in 2013 that necessitated defruiting the vines in 2014. Fruit yields on 'UCD GRN-5' rootstocks were satisfactory in 2013 and 2015 , but the vines eventually deteriorated, with $99 \%$ shootless nodes by 2017 . Although more evaluations of these new rootstocks are needed in the midwestern United States, we conclude that 'UCD GRN-2', 'UCD GRN-3', and 'UCD GRN-4' show promise, whereas 'UCD GRN5 ' does not appear suitable for growing conditions in southern Missouri.

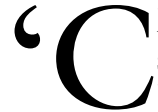
hambourcin' winegrape (Vitis sp.) is a French-American hybrid with a complex pedigree based on Seibel hybrids, released in 1963 (Robinson et al., 2012; UCD, $2020)$. It is a moderately vigorous and highly productive cultivar for the midwestern United States that produces

Received for publication 25 Mar. 2020. Accepted for publication 5 Aug. 2020

Published online 3 September 2020.

${ }^{1}$ University of Missouri, Division of Plant Sciences, Southwest Research Center, Mt. Vernon, MO 65712

${ }^{2} \mathrm{E}$ \& J Gallo Winery, 21280 N. Kennefick Road, Acampo, CA 95220

${ }^{3}$ Crown Valley Winery, 23589 State Route WW, Ste. Genevieve, MO 63670

We gratefully acknowledge the support of the Missouri Wine and Grape Board, Missouri Wine Marketing and Research Council, University of Missouri Grape and Wine Institute, University of Missouri Cooperative Extension Service, Plantra (Eagan, MN), Wonderful Nurseries (Wasco, CA), Roll Forming Corporation (Shelbyville, KY), Reams Irrigation (Nixa, MO), Jim's Supply Co. (Bakersfield, CA), and the many student employees who made this experiment possible.

A.L.T. is the corresponding author. E-mail: thomasal@ missouri.edu.

This is an open access article distributed under the CC BY-NC-ND license (https://creativecommons.org/ licenses/by-nc-nd/4.0/).

https://doi.org/10.21273/HORTTECH04617-20 a red wine favored by regional consumers. With good management, 'Chambourcin' can be economical to produce (Bordelon, 2009; Dami et al., 2005). Most of 'Chambourcin' grown in Missouri and the midwestern United States are own-rooted vines. Although the use of rootstocks offers numerous potential benefits in U.S. viticulture (Christensen, 2003), the horticultural and economic advantages of using rootstocks with 'Chambourcin' in the midwestern United States have not yet been satisfactorily demonstrated (Thomas et al., 2017).
Nematodes, especially root-knot (Meloidogyne sp.), dagger (Xiphinema sp.), and root lesion (Pratylenchus sp.), create sporadic serious viticultural production challenges in the midwestern United States, although notable economic damage is often confined to specific soils and environments (e.g., Bird et al., 1994; Pokharel et al., 2015; Townshend et al., 1975). Nematodes can weaken plants and reduce yields through physical feeding injury to roots, interfering with transport of water and nutrients, fomenting disease, and diverting plant nutrients into the production of galls (Bridge and Starr, 2007). Certain nematodes, especially dagger nematodes, can vector harmful viruses, such as Grapevine fanleaf virus and Tomato ringspot virus (McKenry and Bettiga, 2013; Powell et al., 1990; van Zyl et al., 2012; Villate et al., 2008). Traditional methods to address nematode incidence and damage include the use of soil fumigants and nematicides, and long-term fallowing of land planted to vineyards. Resistant rootstocks have now become one of the most important and effective nematode management strategies in viticulture (Esmenjaud et al., 2011; Ferris et al., 2012).

Milkus (2001) documented two nematode-transmitted viruses ( $\mathrm{To}^{-}$ mato ringspot virus and Arabis mosaic virus) in five Missouri vineyards, and identified american dagger nematode (Xiphinema americanum) in all vineyards sampled. J. Schoelz and D. Volenberg (unpublished data) also identified Tomato ringspot virus in Missouri vineyards and confirmed dagger nematodes (species not determined) in one-third of vineyards sampled. A detailed survey of 30 vineyards in Missouri and Arkansas in 2008 (R.T. Robbins, R.K. Striegler,

\begin{tabular}{llll}
\hline $\begin{array}{l}\text { Units } \\
\text { To convert U.S. to SI, } \\
\text { multiply by }\end{array}$ & U.S. unit & SI unit & $\begin{array}{l}\text { To convert SI to U.S., } \\
\text { multiply by }\end{array}$ \\
\hline 10 & $\%$ & $\mathrm{~g} \cdot \mathrm{L}^{-1}$ & 0.1 \\
0.4047 & $\mathrm{acre}(\mathrm{s})$ & $\mathrm{ha}$ & 2.4711 \\
102.7902 & $\mathrm{acre}-\mathrm{inch}(\mathrm{es})$ & $\mathrm{m}$ & 0.0097 \\
0.3048 & $\mathrm{ft}$ & $\mathrm{m}$ & 3.2808 \\
3.7854 & $\mathrm{gal}$ & $\mathrm{L}$ & 0.2642 \\
2.54 & inch(es) & $\mathrm{cm}$ & 0.3937 \\
25.4 & inch $(\mathrm{es})$ & $\mathrm{mm}$ & 0.0394 \\
0.4536 & $\mathrm{lb}$ & $\mathrm{kg}$ & 2.2046 \\
1.4882 & $\mathrm{lb} / \mathrm{ft}$ & $\mathrm{kg} \cdot \mathrm{m}^{-1}$ & 0.6720 \\
28.3495 & $\mathrm{Oz}$ & $\mathrm{g}$ & 0.0353 \\
2.2417 & $\mathrm{ton}(\mathrm{s}) / \mathrm{acre}$ & $\mathrm{Mg} \cdot \mathrm{ha}^{-1}$ & 0.4461 \\
$\left({ }^{\circ} \mathrm{F}-32\right) \div 1.8$ & ${ }^{\circ} \mathrm{F}$ & ${ }^{\circ} \mathrm{C}$ & $\left({ }^{\circ} \mathrm{C} \times 1.8\right)+32$ \\
& & &
\end{tabular}

Hortlechnology $\cdot$ October $202030(5)$ 
J.L. Harris, R.A. Allen, T. Kirkpatrick, and E.A. Bergmeier, unpublished data) identified two nematode genera (rootknot, root lesion) and one distinctive species (american dagger nematode) of economic importance. In that study, $93 \%$ of vineyards surveyed showed presence of american dagger nematode, with $80 \%$ having populations at medium to high levels defined by McKenry and Bettiga (2013) and for which mitigation measures may be warranted. Because american dagger nematode is known to vector Tomato ringspot virus in grapes, and rootknot and root lesion nematodes are known to cause economic damage to grapevines (McKenry and Bettiga, 2013), efforts to explore the application of nematode-resistant rootstocks in midwestern U.S. viticulture are justified.

Five nematode-resistant rootstocks ('UCD GRN-l', 'UCD GRN2', 'UCD GRN-3', 'UCD GRN-4', and 'UCD GRN-5'), derived from various complex genetic combinations of multiple grape species were released by University of CaliforniaDavis (UCD) in 2008 and patented in 2009-10 (Ferris et al., 2012; Walker and Ferris, 2009). These rootstocks were selected for broad and stable resistance to nematodes, ease of grafting, appropriate vigor, and other favorable attributes. All have been shown to be resistant to root-knot nematode (Meloidogyne incognita Race 3, M. incognita pathotype Harmony C, Meloidogyne arenaria pathotype Harmony A) and dagger nematode (Xiphinema in$d e x)$, and moderately resistant or moderately susceptible to root lesion nematode (Pratylenchus vulnus), pin nematode (Paratylenchus hamatus), ring nematode (Mesocriconema xenoplax), and citrus nematode (Tylenchus semipenetrans) (Ferris et al., 2012). Additional information and specific horticultural attributes for the nematode-resistant rootstocks evaluated in this study are detailed in Ferris et al. (2012).

Although these new rootstocks have been evaluated in multiple California environments, their potential utility under midwestern U.S. environmental conditions is uncertain and heretofore had not been ascertained. Before any rootstock can be recommended for broad use in a region and with a particular scion cultivar, thorough, long-term evaluations are needed. The only other known evaluations of these rootstocks outside of California have been with 'Sangiovese' in the Texas Hill Country (Kamas et al., 2020), and with 'Blanc du Bois' in the Texas Gulf Coast region (Scheiner et al., 2020).

'Couderc 3309' [Vitis riparia $\times$ Vitis rupestris (often and hereafter called 3309C)], is one of the most commonly used rootstocks in U.S. viticulture, and is known for medium vigor, low to medium drought tolerance, and high phylloxera (Daktulosphaira vitifoliae) resistance (Christensen, 2003; Pongrácz, 1983). Various studies have indicated that 3309C has low to moderate nematode resistance, depending on soil type (Harris, 1983; McKenry et al., 2001). It was incorporated into the study as a benchmark (control) rootstock that is well adapted to the region for comparison with the new rootstocks. In addition, own-rooted vines were included in the study because most of 'Chambourcin' produced in the midwestern United States are own-rooted vines.

The resistance of the UCD rootstocks to multiple nematode species found in California vineyards has already been established (Ferris et al., 2012). Although we might hypothesize that these rootstocks will also resist certain nematodes in the midwestern United States, their explicit resistance to known pathogenic species in this environment is currently unknown, and such determination was beyond the scope of this study. The objectives of this study were to evaluate the viticultural characteristics and suitability of four of the new UCD nematoderesistant rootstocks in the midwestern United States by systematically quantifying their performance, and to determine their influence on 'Chambourcin' productivity, fruit composition, scion hardiness, and phenology under southern Missouri environmental conditions.

\section{Materials and methods}

The study was integrated into a larger research vineyard (2 acres) that included additional studies on grafted 'Chambourcin' vines established in 2008 and 2009 at the University of Missouri's Southwest Research Center near Mt. Vernon (lat. $37.074297^{\circ} \mathrm{N}$, long. $93.879708^{\circ} \mathrm{W}$, USDA Plant Hardiness Zone 6a) (Migicovsky et al., 2019; Thomas et al., 2017). The soil was a Hoberg silt loam (fine loamy, siliceous, mesic Mollic Fragiudalfs) that is upland, deep, gently sloping, and moderately well drained to a fragipan at 40 to $90 \mathrm{~cm}$ (Hughes, 1982). Soil was pushed into berms $(\approx 25 \mathrm{~cm}$ high) to form vineyard rows, and vines planted thereon to improve soil drainage and root penetrable soil depth over the fragipan. Drip irrigation [emitters rated $0.42 \mathrm{gal} / \mathrm{h}$ spaced 36 inches (Netafim, Fresno, CA)] was used to supplement rainfall as needed to supply 1 acre-inch of water per week during the growing seasons. Vines in this study were established with paired trunks and trained to high bilateral cordons (single curtain), with average height of $5.8 \mathrm{ft}$ above soil level. More detail on climate, trellis system, and site establishment is provided in Thomas et al. (2017), along with protocols on soil fertilization, pest management, weed control, winter graft union protection, and pruning.

'Chambourcin' scions were benchgrafted to 'UCD GRN-2', 'UCD GRN-3', 'UCD GRN-4', 'UCD GRN-5', and 3309C rootstocks, and own-rooted 'Chambourcin' grapevines were produced and donated by Wonderful Nurseries (Wasco, CA). All were transplanted 16 July 2010 as green-growing potted vines, with graft unions positioned $\approx 5$ inches above soil level to prevent scion rooting. Spacing was $7 \mathrm{ft}$ between vines in-row, and $9.7 \mathrm{ft}$ between rows. Graft unions were afforded winter protection with mounds of mushroom and/or municipal compost (J-M Farms, Miami, OK; City of Monett, Monett, MO, respectively) during the first five winters; the compost was thereafter spread into the vineyard rows each spring. The study was established in a completely randomized block design, with six rootstock treatments (five rootstocks plus own-rooted vines) and four single-row blocks (replications) of each rootstock. Each plot contained two side-by-side vines of the same rootstock, for a total of 48 vines in the study. Additional 'Chambourcin' guard vines were deployed at the row ends and between blocks such that all vines were grown in near-identical environments. 
During the establishment seasons of 2010-12, all inflorescences were removed so that no fruit developed to encourage robust vine establishment. All fruit from the experiment was harvested l Oct. 2013, 30 Sept. 2014, and 3 Oct. 2015. Harvest data included total fruit yield and cluster number per plot. Samples of 100 random ripe berries per plot were collected, weighed, immediately refrigerated, and then analyzed within $2 \mathrm{~d}$ for soluble solids concentration, $\mathrm{pH}$, and titratable acidity in terms of tartaric acid [laboratory methods and instruments used are described in Thomas et al. (2017)]. Mean berry size was calculated, and mean number of berries per cluster calculated by dividing mean cluster weight by mean berry weight. Pruning weight data were collected in Feb./Mar. 2013-16 to quantify vegetative growth during the previous year (2012-15), and Ravaz index (yield/pruning weight) calculated for the 2013-15 growing seasons. Vines were balance-pruned to $20+$ 20 formula $(20$ nodes retained for every $\mathrm{l} \mathrm{lb}$ of pruning weight).

To quantify rootstock influence on scion response to the regional climate, dates of budbreak and shootless nodes data were collected. Spring budbreak date, defined as the date on which $50 \%$ or more of buds among both vines in a plot exhibited emergence of green tissue beneath the bud scales (Dokoozlian, 1999), was recorded in seasons 2016-18. Shootless nodes, defined as count nodes retained during dormant pruning that failed to produce viable shoots, were assayed in July 2017 when eight randomly selected nodes per vine were examined for the presence of live shoot growth. This metric, which measures bud survival and the sustainability of a vine's bearing surface, was used to quantify observed differences between rootstock treatments several years after establishment.

All data were subjected to analyses of variance in the form of a randomized complete block design using a general linear statistical model (SAS version 9.4; SAS Institute, Cary, NC) to elucidate differences in fruit production, fruit characteristics, phenology, and vine size among the rootstocks. Means were separated by Fisher's least significant difference test $(P \leq 0.05)$. The experimental unit was the two-vine plot, thus two-vine plot data means were statistically analyzed; however, all appropriate data are reported on a single-vine basis.

\section{Results and discussion}

'Chambourcin' initially grew satisfactorily on all rootstocks, as well as on its own roots, as demonstrated by acceptable pruning weights after 2.5 years of growth in 2012 (Table 1). For reference, Jordan et al. (1981) recommend optimum pruning weights of 2 to $3 \mathrm{lb} /$ vine (for 'Concord' with 8 -ft cordons) or 0.3 to 0.4 $\mathrm{lb} / \mathrm{ft}$ of cordon, and Kliewer and Casteel (2003) suggest optimal values of 0.2 to $0.4 \mathrm{lb} / \mathrm{ft}$. After the establishment period, the rootstock 'UCD GRN-3' consistently produced pruning weights among the highest recorded, although statistical differences from other rootstocks varied among years. The exception was 'UCD GRN-5', for which pruning weights early in the study (2012, 2013) were lower than most other rootstock treatments. Although 'UCD GRN-5' produced a fruit crop comparable to the other rootstocks in 2013 (detailed yield data not shown), vegetative growth was greatly reduced (likely due to fruiting stress) as indicated by low pruning weights in 2013 , resulting in the decision to de-fruit the vines in 2014. After 1 year of rest, 'UCD GRN-5' produced a fruit crop comparable to the other treatments in 2015 , but, once again, at the expense of vegetative growth; 2015 pruning weights for 'UCD GRN-5' were significantly lower than all other rootstocks, resulting in very high Ravaz indices.

Table 1. Pruning weight and Ravaz index (yield/pruning weight) for 'Chambourcin' winegrape grown on five rootstocks and own-rooted vines at Mt. Vernon, MO in 2012-15.

\begin{tabular}{|c|c|c|c|c|c|c|c|}
\hline \multirow[b]{2}{*}{ Rootstock } & \multicolumn{4}{|c|}{ Pruning wt $(\mathrm{kg} / \mathrm{vine})^{\mathrm{z}}$} & \multicolumn{3}{|c|}{ Ravaz index } \\
\hline & 2012 & 2013 & 2014 & 2015 & 2013 & 2014 & 2015 \\
\hline Own & 1.66 & $0.78 \mathrm{abc}^{\mathrm{y}}$ & 0.87 & $0.98 \mathrm{a}$ & 24.0 & $11.1 \mathrm{~b}$ & $10.5 \mathrm{~b}$ \\
\hline 3309C & 1.52 & $0.88 \mathrm{ab}$ & 0.84 & $1.19 \mathrm{a}$ & 16.8 & $13.1 \mathrm{~b}$ & $9.7 \mathrm{~b}$ \\
\hline UCD GRN2 & 1.46 & $0.72 \mathrm{bc}$ & 0.71 & $0.98 \mathrm{a}$ & 19.4 & $15.4 \mathrm{ab}$ & $8.6 \mathrm{~b}$ \\
\hline UCD GRN3 & 1.57 & $1.08 \mathrm{a}$ & 0.91 & $1.38 \mathrm{a}$ & 9.0 & $15.4 \mathrm{ab}$ & $7.0 \mathrm{~b}$ \\
\hline UCD GRN4 & 1.55 & $0.71 \mathrm{bc}$ & 0.68 & $1.00 \mathrm{a}$ & 23.4 & $20.2 \mathrm{a}$ & $8.8 \mathrm{~b}$ \\
\hline UCD GRN5 & 1.26 & $0.55 \mathrm{c}$ & - & $0.50 \mathrm{~b}$ & 25.0 & - & $24.6 \mathrm{a}$ \\
\hline$P$ value & 0.5891 & 0.0470 & 0.3165 & 0.0102 & 0.2355 & 0.0480 & 0.0170 \\
\hline
\end{tabular}

${ }^{\mathrm{z}}$ Pruning weight data for the given year were collected in February/March of the following year; data are singlevine means from two-vine plots. To convert this mean per-vine total pruning weight data to cane weight per unit of cordon length [total length $7 \mathrm{ft}(2.1 \mathrm{~m})$ ], divide number by $2.1336 \mathrm{for} \mathrm{kg} \cdot \mathrm{m}^{-1}$, or multiply by $0.3149 \mathrm{for} \mathrm{lb} / \mathrm{ft}$.

${ }^{y}$ Means within columns with the same letters are not different according to Fisher's least significant difference test $(P<0.05)$. 
Table 2. 'Chambourcin' winegrape fruit yields, and cluster, berry, and juice characteristics grown on five rootstocks and ownrooted vines at Mt. Vernon, MO in 2013-15.

\begin{tabular}{|c|c|c|c|c|c|c|c|c|c|}
\hline Factor & Subfactor & $\begin{array}{l}\text { Fruit yield } \\
{\text { (kg/vine })^{z}}\end{array}$ & $\begin{array}{c}\text { Clusters } \\
\text { (no./vine) }\end{array}$ & $\begin{array}{l}\text { Cluster } \\
\text { wt }(g)^{y}\end{array}$ & $\begin{array}{c}\text { Berries } \\
\text { (no./ } \\
\text { cluster) }\end{array}$ & $\begin{array}{c}\text { Single } \\
\text { berry wt } \\
(\mathrm{g})\end{array}$ & $\begin{array}{l}\text { SSC } \\
(\%)^{x}\end{array}$ & $\mathrm{pH}$ & $\begin{array}{c}\text { TA } \\
\left(\mathrm{g} \cdot \mathrm{L}^{-1}\right)^{\mathrm{y}, \mathrm{w}}\end{array}$ \\
\hline \multirow[t]{3}{*}{ Year $(\mathrm{Y})$} & 2013 & $13.3 \mathrm{a}^{\mathrm{v}}$ & $72 \mathrm{a}$ & $185 \mathrm{~b}$ & $85 \mathrm{~b}$ & $2.17 \mathrm{~b}$ & $21.6 \mathrm{~b}$ & $3.55 \mathrm{~b}$ & $6.96 \mathrm{a}$ \\
\hline & 2015 & $9.6 \mathrm{~b}$ & $56 \mathrm{~b}$ & $167 \mathrm{~b}$ & $69 c$ & $2.43 \mathrm{a}$ & $21.7 \mathrm{~b}$ & $3.67 \mathrm{a}$ & $6.31 \mathrm{~b}$ \\
\hline & $P$ value & $<0.0010$ & $<0.0001$ & $<0.0001$ & $<0.0001$ & $<0.0001$ & $<0.0001$ & $<0.0001$ & $<0.0001$ \\
\hline \multirow{5}{*}{ Rootstock (R) } & UCD GRN-2 & 10.8 & 54 & 204 & 86 & $2.36 \mathrm{ab}$ & $22.0 \mathrm{ab}$ & $3.641 \mathrm{a}$ & $6.57 \mathrm{a}$ \\
\hline & UCD GRN-3 & 10.9 & 55 & 197 & 84 & $2.37 \mathrm{ab}$ & $22.4 \mathrm{a}$ & $3.625 \mathrm{ab}$ & $6.50 \mathrm{a}$ \\
\hline & UCD GRN-4 & 12.1 & 56 & 221 & 96 & $2.28 \mathrm{bc}$ & $22.1 \mathrm{ab}$ & $3.616 \mathrm{ab}$ & $6.46 \mathrm{ab}$ \\
\hline & UCD GRN-5 $5^{\mathrm{u}}$ & 11.6 & 67 & 179 & 81 & $2.21 \mathrm{c}$ & $22.2 \mathrm{ab}$ & $3.628 \mathrm{ab}$ & $6.22 \mathrm{bc}$ \\
\hline & $P$ value & 0.8533 & 0.6637 & 0.2410 & 0.1158 & 0.0108 & 0.0001 & 0.0015 & $<0.0001$ \\
\hline $\mathrm{Y} \times \mathrm{R}$ & $P$ value & 0.1899 & 0.1278 & 0.7376 & 0.6037 & 0.0490 & 0.3417 & 0.7590 & 0.0170 \\
\hline
\end{tabular}

${ }^{\mathrm{z}}$ Data are single-vine means from two-vine plots; $1 \mathrm{~kg}=2.2046 \mathrm{lb}$.

${ }^{\mathrm{y}} 1 \mathrm{~g}=0.0353 \mathrm{oz}$.

xSoluble solids concentration.

${ }^{\mathrm{w}}$ Titratable acidity in terms of tartaric acid; $1 \mathrm{~g} \cdot \mathrm{L}^{-1}=0.1 \%$

${ }^{v}$ Means within sub-columns with the same letters are not different according to Fisher's least significant difference test $(P<0.05)$.

"Values do not include data from 'UCD GRN-5' in 2014, which was de-fruited that year.

et al., 1999). The GRN rootstocks all produced berries with higher soluble solids concentration (collective mean $22.2 \%$ ) compared with ungrafted vines (21.2\%), but only 'UCD GRN-3' was higher than 3309C for this parameter. Although some effect of rootstock was observed for $\mathrm{pH}$ and titratable acidity, values for fruit grown on the GRN rootstocks generally were near or between those for $3309 \mathrm{C}$ and ungrafted vines. When evaluating growing year $\times$ rootstock statistical interactions, the only factors that were affected were single berry weight and titratable acidity.

Observed weather during this experiment was generally representative of a midwestern U.S. continental climate, with routine seasonal fluctuations in temperatures and precipitation, and occasional temperature extremes (Table 3). Although extreme temperatures are, by definition, rare, their "frequent" occurrence in the midwestern United States presents a perpetual challenge to economical winegrape production in the region. Maximum summer temperature and seasonal heat summation data (growing degree days, base $50{ }^{\circ} \mathrm{F}$ ) confirm exceptionally hot summers during the establishment years of 2011 and 2012. More normal temperatures occurred during the data years of 2013-15, except for extreme cold during the winter of 2013-14. Despite these seasonal weather challenges, summer irrigation should have reduced moisture stress during dry periods / seasons, and winter graft union protection should have mitigated freezing stresses somewhat during this experiment.

The challenges observed in this study with 'Chambourcin' scions grafted to 'UCD GRN-5' are difficult to explain given a limited dataset. One plausible explanation is that 'UCD GRN-5' may simply not be adapted to the environmental conditions under which this experiment was conducted, and may have suffered freeze damage or other abiotic stress. A second is that 'UCD GRN5' may be a low capacity or lateestablishing rootstock; early cropping stresses may have permanently weakened the vines, thereby directly and/ or indirectly increasing susceptibility to additional stresses. When 'UCD GRN-5' vines suffered damage during the first years of the study, both the rootstock and 'Chambourcin' scion survived, and cordons were reestablished from epicormic buds repeatedly as necessary. By 2017, however, nearly all the 'UCD GRN5 ' vines had suffered significant longterm cordon or whole vine damage as they continued to weaken. Of eight 'UCD GRN-5' nodes evaluated per vine in July 2017, 7.9 nodes were shootless, whereas the other rootstock treatments continued to thrive
(Table 4). Although spring frost/ freeze injury was not visibly evident during this experiment, budbreak data show that 'UCD GRN-5' apparently hastened spring budbreak by 2 to $3 \mathrm{~d}$ in 2016 and 3 to $5 \mathrm{~d}$ in 2018 , possibly increasing the potential risk of late spring freeze damage (Johnson and Howell 1981; Kovacs et al., 2003). Grapevine rootstocks have been shown to influence scion phenology and budbreak in numerous cultivars (e.g., Ferroni and Scalabrelli, 1995; Menora et al., 2015; Neal et al., 2016; Reddy, 1990).

Kamas et al. (2020) and Scheiner et al. (2020) evaluated these same nematode-resistant rootstocks ('UCD GRN-2', 'UCD GRN-3', 'UCD GRN-4', and 'UCD GRN-5'), along with additional rootstocks, grafted to 'Sangiovese' and 'Blanc du Bois', respectively, in Texas. 'UCD GRN-5' performed poorly on a $\mathrm{pH} 8.5$ soil with 'Sangiovese' (attributed to $\mathrm{pH}$ induced nutritional deficiency), but all four performed satisfactorily on a $\mathrm{pH}$ 8.1 soil with 'Blanc du Bois' and a $\mathrm{pH}$ 6.6 soil with 'Sangiovese'. In the 'Sangiovese' study on $\mathrm{pH} 6.6$ soil, the UCD rootstocks did not statistically influence fruit yields compared with own-rooted vines; however, 'UCD GRN-5' produced among the lowest pruning weights and among the lowest number of berries per cluster. Similarly, the UCD rootstocks grafted to 'Blanc du Bois' did not statistically 
Table 3. Maximum (Max) and minimum (Min) ambient temperatures, total annual precipitation, and growing degree days [base $50{ }^{\circ} \mathrm{F}\left(10.0^{\circ} \mathrm{C}\right)$ ] recorded at or near the study of 'Chambourcin' winegrape grown on five rootstocks and own-rooted vines at Mt. Vernon, MO in 2010-17.

\begin{tabular}{|c|c|c|c|c|c|c|c|c|c|c|}
\hline Factor $^{\mathrm{z}}$ & Period & Avg & 2010 & 2011 & 2012 & 2013 & 2014 & 2015 & 2016 & 2017 \\
\hline Max temp $\left({ }^{\circ} \mathrm{F}\right)^{\mathrm{y}}$ & July-Aug. & 89.1 & - & $110^{\mathrm{w}}$ & $108^{w}$ & 98 & $101^{\mathrm{w}}$ & 95 & 99 & 95 \\
\hline Min temp $\left({ }^{\circ} \mathrm{F}\right)^{\mathrm{x}}$ & Dec.-Feb. & 23.4 & $-13^{\mathrm{w}}$ & 5 & 9 & $-12^{\mathrm{w}}$ & -2 & 5 & -3 & - \\
\hline Growing degree days $\left({ }^{\circ} \mathrm{F}\right)$ & 1 Apr.-31 Oct. & 3891 & - & 4335 & 4418 & 4052 & 3919 & 4026 & 4251 & 3760 \\
\hline
\end{tabular}

${ }^{\mathrm{z}}$ Weather data compiled from multiple sources, including manual recording and Commercial Agriculture Automated Weather Station Network, Mt. Vernon and Lamar, MO (University of Missouri, 2020), and National Oceanic and Atmospheric Administration (2020).

${ }^{\mathrm{y}}\left({ }^{\circ} \mathrm{F}-32\right) \div 1.8={ }^{\circ} \mathrm{C}, 1$ inch $=25.4 \mathrm{~mm}$.

${ }^{\mathrm{x}}$ Minimum temperature is for the entire winter season beginning in the designated calendar year and continuing into the following year.

"This maximum or minimum temperature fell within the $\leq 5 \%$ range of days per month to reach or surpass that temperature, thus defined as "extreme" (National Oceanic and Atmospheric Administration, 2020).

Table 4. Budbreak and shootless node data for 'Chambourcin' winegrape grown on five rootstocks and own-rooted vines at Mt. Vernon, MO in 2016-18.

\begin{tabular}{lcccc}
\hline Rootstock & $\begin{array}{c}\text { Budbreak 2016 } \\
\text { (day of the yr) }^{\mathrm{z}}\end{array}$ & $\begin{array}{c}\text { Budbreak 2017 } \\
\text { (day of the yr) }^{-}\end{array}$ & $\begin{array}{c}\text { Budbreak 2018 } \\
\text { (day of the yr) }\end{array}$ & $\begin{array}{c}\text { Shootless nodes } \\
\text { (no./vine) }^{\mathrm{y}}\end{array}$ \\
\hline Own & $99.5 \mathrm{a}^{\mathrm{x}}$ & $89.8 \mathrm{a}$ & $115.0 \mathrm{ab}$ & $0.0 \mathrm{~b}$ \\
3309C & $98.5 \mathrm{a}$ & $88.2 \mathrm{ab}$ & $116.2 \mathrm{ab}$ & $0.0 \mathrm{~b}$ \\
UCD GRN-2 & $99.9 \mathrm{a}$ & $86.9 \mathrm{~b}$ & $114.6 \mathrm{~b}$ & $0.0 \mathrm{~b}$ \\
UCD GRN-3 & $99.6 \mathrm{a}$ & $86.6 \mathrm{~b}$ & $117.0 \mathrm{a}$ & $0.3 \mathrm{~b}$ \\
UCD GRN-4 & $99.9 \mathrm{a}$ & $87.0 \mathrm{~b}$ & $115.9 \mathrm{ab}$ & $0.0 \mathrm{~b}$ \\
UCD GRN-5 & $96.5 \mathrm{~b}$ & - & $111.8 \mathrm{c}$ & $7.9 \mathrm{a}$ \\
Pvalue & 0.0017 & 0.0057 & 0.0030 & $<0.0001$ \\
\hline
\end{tabular}

${ }^{\mathrm{z}}$ Data are day of the year from 1 Jan.

${ }^{\mathrm{y}}$ Mean number of shootless nodes among eight random nodes surveyed per vine, July 2017 , to assess vine viability well into the growing season.

${ }^{\mathrm{x}}$ Means within columns with the same letters are not different according to Fisher's least significant difference test $(P<0.05)$.

influence pruning weight, and only 'UCD GRN-4' increased fruit yields compared with own-rooted vines in 1 production year.

Because the rootstocks 'UCD GRN-2', 'UCD GRN-3', and 'UCD GRN-4' generally performed similarly to the standard 3309C and own-rooted vines under identical ambient conditions in our study, we can conclude that they show promise for use in midwestern U.S. winegrape production. 'UCD GRN-3' was statistically more vigorous and produced fruit with a higher soluble solids concentration compared with most other rootstocks or own-rooted vines. Concurrently, our study indicates that 'UCD GRN-5' may not be suitable for southern Missouri growing conditions, and presumably USDA Hardiness Zone $6 a$ and colder zones. Although these rootstocks are resistant to the enumerated nematodes in California (Ferris et al., 2012), they have not been specifically tested for resistance to nematode species and races that are prevalent in the midwestern United States. In particular, although the rootstocks are resistant to dagger nematode, their resistance to american dagger nematode, which is of greater concern in the midwestern United States, is presently unknown. This was the first significant trial of these new nematode-resistant rootstocks in the midwestern United States; more testing is needed, including an evaluation of the rootstocks' resistance to problematic nematodes in the region, before they can be recommended with confidence.

\section{Literature cited}

Bird, G., J. Davenport, F. Warner, and C. Diamond. 1994. Distribution and regulation of Meloidogyne nataliei. J. Nematol. 26:727-730.

Bordelon, B. 2009. Grape varieties for Indiana. Purdue Univ., Purdue Ext. HO221-W.

Boulton, R.B., V.L. Singleton, L.F. Bisson, and R.E. Kunkee. 1999. Principles and practices of winemaking. Springer, New York, NY.

Bridge, J. and J.L. Starr. 2007. Plant nematodes of agricultural importance: A colour handbook. Manson Publ., London, UK.

Christensen, L.P. 2003. Rootstock selection, p. 12-15. In: L.P. Christensen, N.K. Dokoozlian, M.A. Walker, and J.A. Wolpert (eds.). Wine grape varieties in California. Univ. California Agr. Nat. Resour. Publ. 3419.

Dami, I., D.C. Ferree, S.K. Kurtural, and B.H. Taylor. 2005. Influence of crop load on 'Chambourcin' yield, fruit quality, and winter hardiness under midwestern United States environmental conditions. Acta Hort. 689:203-208.

Dokoozlian, N.K. 1999. Chilling temperature and duration interact on the budbreak of 'Perlette' grapevine cuttings. HortScience 34:1054-1056.

Esmenjaud, D., M. van Helden, N. Ollat, A. Bouquet, and G. Demangeat. 2011. Nematode- resistant rootstocks as a major component of the management alternative for Grapevine fanleaf virus control in grape. Acta Hort. 904:111-115.

Ferris, H., L. Zheng, and M.A. Walker. 2012. Resistance of grape rootstocks to plant-parasitic nematodes. J. Nematol. 44:377-386.

Ferroni, G. and G. Scalabrelli. 1995. Effect of rootstock on vegetative activity and yield in grapevine. Acta Hort. 388:37-42.

Harris, A.R. 1983. Resistance of some Vitis rootstocks to Xiphinema index. J. Nematol. 15:405-409.

Hughes, H.E. 1982. Soil survey of Greene and Lawrence counties, Missouri. 
U.S. Dept. Agr. Soil Conserv. Serv., Missouri Agr. Exp. Stn., Columbia, MO.

Johnson, D.E. and G.S. Howell. 1981. Factors influencing critical temperatures for spring freeze damage to developing primary shoots on Concord grapevines. Amer. J. Enol. Viticult. 32:144-149.

Jordan, T.D., R.M. Pool, T.J. Zabadal, and J.P. Tomkins. 1981. Cultural practices for commercial vineyards. New York State College Agr. Life Sci. Misc. Bull. 111.

Kamas, J., A. Labay, and J.J. Scheiner. 2020. Evaluation of grapevine rootstocks on slightly acidic and strongly alkaline Texas Hill Country soils. Catalyst 4, doi: 10.5344/catalyst.2020.19006.

Kliewer, W.M. and T. Casteel. 2003. Canopy management, p. 177-184. In: E.W. Hellman (ed.). Oregon viticulture. Oregon State Univ. Press, Corvallis, OR.

Kovacs, L.G., P.L. Byers, M.L. Kaps, and J. Saenz. 2003. Dormancy, cold hardiness, and spring frost hazard in Vitis amurensis hybrids under continental climate conditions. Amer. J. Enol. Viticult. 54:8-14.

McKenry, M.V., J.O. Kretsch, and S.A. Anwar. 2001. Interactions of selected rootstocks with ectoparasitic nematodes. Amer. J. Enol. Viticult. 52:304-309.

McKenry, M.V. and L.J. Bettiga. 2013. Nematodes, p. 449-470. In: L.J. Bettiga (ed.). Grape pest management. Univ. California Agr. Nat. Resour. Publ. 3343.

Menora, N.D., V. Joshi, V. Kumar, D. Vijaya, M.K. Debnath, S. Pattanashetty, A.S. Padmavathamma, M.T. Variath, S. Biradar, and S. Khadakabhavi. 2015. Influence of rootstock on bud break, period of anthesis, fruit set, fruit ripening, heat unit requirement and berry yield of commercial grape varieties. Intl. J. Plant Breed. Genet. 9:126-135.
Migicovsky, Z., Z.N. Harris, L.L. Klein, M. Li, A. McDermaid, D.H. Chitwood, A. Fennell, L.G. Kovacs, M. Kwasniewski, J.P. Londo, Q. Ma, and A.J. Miller. 2019. Rootstock effects on scion phenotypes in a 'Chambourcin' experimental vineyard. Hort. Res. 6:64.

Milkus, B.N. 2001. Incidence of four NEPO viruses in Missouri vineyards. Amer. J. Enol. Viticult. 52:56-57.

National Oceanic and Atmospheric Administration. 2020. North American climate extremes monitoring. 21 May 2020. $<$ https://www.ncdc.noaa.gov/ extremes/nacem/methodology $>$.

Neal, S.M., A.P. Friend, M.C.T. Trought, A.R.G. McLachlan, and P.E. Read. 2016. The performance of 'Sauvignon Blanc' on five grapevine rootstocks in a Marlborough vineyard. Acta Hort. 1115:147154.

Pokharel, R., D.J. Chitwood, S.P. Marahatta, and Z.A. Handoo. 2015. Nematode community structures in different deciduous tree fruits and grape in Colorado, USA and impact of organic peach and apple production practices. Eur. J. Soil Biol. 67:5968 .

Pongrácz, D.P. 1983. Rootstocks for grape-vines. David Philip Publ., Cape Town, South Africa.

Powell, C.A., L.B. Forer, and J.L. Longnecker. 1990. Incidence of tomato ringspot virus and tobacco ringspot virus in grapevines in Pennsylvania. Plant Dis. 74:702-704.

Reddy, N.N. 1990. Effect of different rootstocks on budbreak in grape cv. Anab-e-Shahi. Crop Research (Hisar) 3:51-55.
Robinson, J., J. Harding, and J. Vouillamoz. 2012. Wine grapes. HarperCollins, New York, NY.

Scheiner, J.J., A. Labay, and J. Kamas. 2020. Rootstocks improve Blanc du Bois vine performance and fruit quality on alkaline soil. Catalyst 4, doi: 10.5344/ catalyst.2020.19007.

Thomas, A.L., J.L. Harris, E.A. Bergmeier, and R.K. Striegler. 2017. Establishment technique and rootstock impact 'Chambourcin' grapevine morphology and production in Missouri. HortTechnology 27:248-256.

Townshend, J.L., A.E. Neff, and C.F. Marks. 1975. Effect of fumigation on growth of grape rootstocks on soil infested with root-lesion nematodes. Plant Dis. Rep. 59:776-779.

University of California, Davis (UCD). 2020. National grape registry. 25 June 2020. <https://fps.ucdavis.edu// fgrabout.cfm $>$.

University of Missouri. 2020. Missouri historical agricultural weather database. 10 Feb. 2020. <http://agebb.missouri. edu/weather/history/index.asp $>$.

van Zyl, S., M.A. Vivier, and M.A. Walker. 2012. Xiphinema index and its relationship to grapevines: A review. S. Afr. J. Enol. Vitic. 33:21-32.

Villate, L., O. Plantard, D. Esmenjaud, M. Van Helden, V. Fievet, B. Hanse, and F. Delemarre. 2008. Spatial distribution of the dagger nematode Xiphinema index and its associated Grapevine fanleaf virus in French vineyard. Phytopathology 98:942-948.

Walker, A. and H. Ferris. 2009. Nematoderesistant rootstocks released to nurseries. Practical Winery Vineyard 2009(Jan):1-3. 